\title{
ENERGY-GROWTH NEXUS: EVIDENCE FROM NIGERIA
}

\author{
Umar Muhammad Dabachi ${ }^{1}$, Suraya Mahmood ${ }^{2}$ \\ Faculty of Business and Management, Universiti Sultan Zainal Abidin, Malaysia ${ }^{12}$
}

Article DOI: https://doi.org/10.36713/epra7175

DOI No: 10.36713/epra7175

\begin{abstract}
-
This study aims to investigate the causality relationships between energy consumption, energy intensity, oil price and economic growth. Regarding the data analysis, the study covered the period from 1980 until 2020. All relevant preliminary tests were conducted in order to validate the data before the main analysis. We deployed ARDL bound test of cointegration approach for long-run relationship, as well as the granger causality test proposed by Toda and Yamamota (1995). The empirical results showed the presence of long-run relationship among the variables. We also found that energy consumption and economic growth has a bidirectional relationship. Similarly, we observed a presence of another feedback causal effect between energy intensity and economic growth. Likewise, a bi-directional causal relationship exists between oil price and economic growth in the Nigerian economy. The study makes available policy recommendations in the last part of the paper.
\end{abstract}

KEY WORDS: energy intensity, energy price, economic growth, Toda and Yamamota-

\section{INTRODUCTION}

Africa has been growing steadily for a decade, with an average yearly GDP gain of 5\%, despite several global crises. Africa is home to seven of the world's 10 fastest-growing economies. This rapid expansion raises interest in Africa and transforms its image from one of civil conflicts, turmoil, and poverty to one of hope, trade, and wealth. We think that one important issue connected with this fast expansion is energy, and our study contributes to the research by examining the importance of energy in Africa's economic growth.

In actuality, energy conservation increases economic opportunities, reduces travel expenses, and improves the industrial sector, all of which contribute to urban change (21). Because energy is a necessary input in the cumulative production process, it has been strongly related to economic growth. As a result, the connection between economic development and energy policy is widely assumed to be tight. However, a country's best energy strategy will be influenced by the opportunity for change in the energy growth axis.

If it helps to lower energy bills, product and service costs, and greenhouse gas emissions, energy conservation in the manufacturing, agricultural, retail, and housing industries may be a focus. Energy-saving methods will result in improved resource allocation by shifting labor and money from the energy industry to a more productive sector. Energy conservation regulations, on the other hand, will stifle economic growth if a country's output is excessively reliant on oil. As a result, policymakers must understand the causal link between energy use and economic growth.

The causal link between energy consumption and economic growth has been represented in four hypotheses (7). (3). According to the demand theory, energy use, both explicitly and as a supplement to labor and capital, has a significant influence on the economic growth cycle (2). The theory of growth is justified if one-way causation between energy use and economic growth can be established. In this instance, the energy reliance on the relevant country's economic performance is so great that changes in energy supply would have a negative impact on economic growth.

Energy-saving programs can have a negative impact on economic growth in the framework of the growth hypothesis. The influence of technical advancements on energy efficiency can be so powerful in the long term that it results to a drop in the energy dependency of the productive process while capital utilization grows, as long as a universality link between power and capital is believed. 
Volume: 9 | Issue: 5 |August 2021 || SJIF Impact Factor (2021): 7.254 || Journal DOI: 10.36713/epra1213

Compared with other studies in the literature, the unique part of this study are: (i) the use of heterogeneous econometrics techniques in addressing the relationship effects among the two sectors, (ii) its consideration of various segments of the energy sector concerning the economic growth of the sampled countries, (iii) the ability of the paper to draw the attention of the stakeholders into the understanding of how relevant these different units of the energy sector are to the growth of the Nigerian economy (v) being major oilexporting country in the continent with the relatively weak economic system, this data will be helpful to the stake-holders, more especially the policymakers in understanding the impact of the energy sector from all of its dimension to growth. The data might also reveal the vulnerability of the oil shocks to the country's economic system and offer a chance to boost the economic growth of this oil-exporting African economy from an energy perspective.

\section{LITERATURE REVIEW}

The breakdown of the Bretton Woods system in 1971 and the first oil shocks in 1973 put certain traditional macroeconomic systems, such as the distribution process, in jeopardy. Nonetheless, a worldwide recession preceded the sharp rise in oil prices caused by the Organization of Petroleum Exporting Countries' oil embargo (OPEC). Several groundbreaking research were undertaken during this time period $(5,6,9,16$, and 22) to look at the relationship between oil price shocks and economic activity in order to see if the reported slump (in the 1970s) was caused by the 1973 oil shock.

(18) is the most significant article in this topic; he suggested that, with the exception of the 1960 recession, oil price hikes were at least substantially responsible for every post-second world war US recession. In contrast to the above-mentioned ground-breaking projects, which were tied to the US economy (18). There is a link between US economic development and oil price movement, according to these researches. Following these researches, a slew of further investigations in a variety of fields were done.

As a result, this study used simultaneous equations models using panel data from OPEC African nations to investigate the causal links between energy price, energy intensity, energy consumption, and economic development. (17), on the other hand, looked at the causation between trade openness, economic growth, and energy use. The use of panel VECM, FMOLS, and DOLS to a panel data analysis of Asian nations was applied. The correlation between economic growth, trade openness, and energy use has been deduced.

While the FMOLS and DOLS estimate analyses show a positive association between energy consumption and economic growth, energy consumption and trade openness, an inverse link between energy consumption and energy prices is detected. Similarly, to investigate the relationship between trade openness, energy consumption, and economic growth in Iran. (14) used the Bayer and Hanck co-integration test, as well as the Vector Error Correction Model. This study's findings indicate the presence of co-integration among the variables. In the short run, the causality findings revealed a unidirectional link between energy use and trade openness.

Meanwhile, the long-run connection test revealed bidirectional causation between economic growth and energy consumption, as well as between openness and energy use, as well as unidirectional causation from openness to economic growth. Given that industrialized nations have seen fast industrialization, economic development, and growth as a result of high energy usage for industrial and other economic activities, it appears and implies that emerging nations would follow in their footsteps.

According to the UN (3). Oil, coal, and gas not only fueled the country's industrialisation, but they also contributed significantly to economic prosperity and social well-being. As a result, carbon dioxide emissions from power plants account for around two-thirds of total $\mathrm{CO} 2$ emissions. As the global economy expands, so does the quantity of carbon emitted by the energy industry. Nonetheless, it calls into question the drive for environmental preservation and sustainable economic growth, both of which are regarded as critical to the world's long-term goals for economic and social progress.

Such changes eventually give rise to many debates on the significance of rising energy consumption, particularly from non-renewable sources, to the progress of emerging countries. Initiatives call for the replacement of non-renewable energy sources with renewable energy as part of climate change mitigation and environmental pollution policies. Empirical study into the connection between environmental deterioration and economic growth in emerging nations is thus critical to their short- and long-term energy plans. Similarly, (6) uses the South African economy to compare energy consumption, carbon dioxide emissions, and economic development. The (5) combined co-integration methodology, the (20) limits test, and the Kripfganz and Schneider causality test were all investigated. The findings demonstrated that there was a one-way causation from energy usage to economic development, hence validating the energy-led growth concept. As a result, (23) discovered a link between energy usage, real GDP per capita, and carbon emissions in Zimbabwe. The ZivotAndrews, Maki co-integration, DOLS, and Toda-Yamamoto causality tests were used in the investigation. There 
Volume: 9 | Issue: 5 |August 2021 || SJIF Impact Factor (2021): 7.254 || Journal DOI: 10.36713/epra1213

is a long-run positive link between electricity consumption and real GDP per capita, as well as a one-way causation going from energy consumption to growth.

\section{EMPIRICAL METHODOLOGY AND DATA}

The Solow development model was applied in this study, which was initially proven by Mankiw (17) on the eve of Islam's (1995) in the panel data research. Consider the Cobb-Douglas growth model: Whereas the output is the capital, the labor force is the output; in the meantime, are (7), (14), (16), and (17). As a result, the current study expands the above-mentioned equation (1) by incorporating energy consumption, energy costs, and energy intensity, yielding the functional form shown below:

$$
\boldsymbol{Y}=\boldsymbol{F}(\boldsymbol{K}, \boldsymbol{M}, \boldsymbol{A})
$$

Where $\mathrm{Y}$ represents total output, $\mathrm{M}$ denotes labor input, $\mathrm{K}$ stands for capital, while A denotes the level of technology, which paves the way for the other determinants.

The Econometrics Model is given as:

$$
L G D P_{i t}=\beta_{0}+\gamma_{1 i} L E C_{i t}+\gamma_{2 i} L E I N_{i t}+\gamma_{3 i} L O P_{i t}+u_{i t}
$$

Where GDP is the economic growth, the EC represents the energy consumption, EIN denotes energy intensity and OP stands for oil price, while $\boldsymbol{u}$ is the error term, and $\boldsymbol{i} \boldsymbol{t}$ represents the cross-sectional countries and years.

Further, the study employed Toda \& Yamamoto (1995) test. Toda and Yamamoto's (TY) technique adapts the VAR model to series levels, reducing the risk associated with the tendency to misidentify the series' order of integration [17]. Concerning the TY test, there is no requirement for the sequence of variable integration before doing a causality analysis. In other words, the test of long-run causation raises the VAR's proper order (optimal lag, k) by the maximum integration order (maximum difference, Dmax), ensuring the typical asymptotic distribution of test statistics for Granger causality [26]. Thus, the TY technique can be used whether the series is I (0), I (1), or I (2). [29] contended that TY eliminates the Granger causality test-related power and size distortions concern. When the enhanced VAR $(\mathrm{k}+\mathrm{dmax})$ is estimated at the greatest level of integration, the TY employs a Modified Wald (MWALD) test, which ensures that the test statistics have an asymptotic chi-square distribution with $\mathrm{k}$ degrees of freedom inside the limit. When applying a MWALD test of long-run causality, the lagged Dmax function is removed. Because of a bivariate relationship, Toda and Yamamoto's causality analysis may be represented as follows:

$$
\begin{gathered}
\Delta L G D P_{i, t}=\beta_{i}+\sum_{k=1}^{K} \partial_{i}^{(k)} \Delta L E C_{i, t-k}+\sum_{k=1}^{K} \partial_{i}^{(k)} \Delta L E I N_{i, t-k}+\sum_{k=1}^{K} \gamma_{i}^{(k)} \Delta L O P_{i, t-k}+\varepsilon_{i, t} \\
\Delta L E C_{i, t} \\
=\beta_{i}+\sum_{k=1}^{K} \gamma_{i}^{(k)} \Delta L G D P_{i, t-k}+\sum_{k=1}^{K} \partial_{i}^{(k)} \Delta L E I N_{i, t-k}+\sum_{k=1}^{K} \delta_{i}^{(k)} \Delta L O P_{i, t-k}+\varepsilon_{i, t} \\
\Delta L E I N_{i, t}=\beta_{i}+\sum_{k=1}^{K} \delta_{i}^{(k)} \Delta L G D P_{i, t-k}+\sum_{k=1}^{K} \gamma_{i}^{(k)} \Delta L E C_{i, t-k}+\sum_{k=1}^{K} \partial_{i}^{(k)} \Delta O P_{i, t-k}+\varepsilon_{i, t}
\end{gathered}
$$


Volume: 9 | Issue: 5 |August 2021 || SJIF Impact Factor (2021): 7.254 || Journal DOI: 10.36713/epra1213

$$
\Delta L O P_{i, t}=\beta_{i}+\sum_{k=1}^{K} \theta_{i}^{(k)} \Delta L G D P_{i, t-k}+\sum_{k=1}^{K} \delta_{i}^{(k)} \Delta L E I N_{i, t-k}+\sum_{k=1}^{K} \gamma_{i}^{(k)} \Delta L E C_{i, t-k}+\varepsilon_{i, t}
$$

Where $\boldsymbol{\beta}_{\boldsymbol{i}}$ is the constant, and $\boldsymbol{K}$ stands as the constant lag. $\boldsymbol{\partial}_{i}^{(\boldsymbol{k})}, \boldsymbol{\gamma}_{i}^{(\boldsymbol{k})}, \boldsymbol{\delta}_{i}^{(\boldsymbol{k})}$ and $\boldsymbol{\theta}_{i}^{(\boldsymbol{k})}$ represents the slope coefficient and autoregressive vectors to vary among the groups. The model uses a fixed individual effect and the fixed coefficient model. The probability value and F-statistics value which depicts whether or not to reject the null hypothesis, account the existence of causality or not, respectively.

The present study consists of 258 observations obtained from the World Development Indicators and the West Texas Intermediate (WTI). The data spread over forty-four (44) years from 1980 to 2020 . We analyze the causal relationship between energy use, energy intensity, energy price and economic growth in Nigeria, using Toda \& Yamamoto Granger causality technique.

The energy price indicator was derived by measuring the market prices of different barrels of oil divided by (CPI) Consumer Price Index for the respective countries. We measure energy use by $\mathrm{kg}$ of oil equivalent per capita. Meanwhile, energy intensity was calculated by dividing the overall primary energy consumption by the Gross Domestic Product expressed in US dollars by purchasing power parity. Furthermore, finally, we proxy economic growth through GDP annual growth.

\section{EMPIRICAL RESULTS}

\subsection{Descriptive Summary}

The descriptive statistics and pair-wise correlation matrix are provided in Table 1. The results show that GDP is highly volatile than EU, and EI is less volatile than EP. Further, the standard deviation is higher for GDP than for the rest of the variables. Skewness and kurtosis show potential asymmetry in the data distribution. Hence, we rely on asymmetric rather than symmetric empirical analyses. The correlation analysis indicates no potential issue of multicollinearity among the variables.

Table 1 Summary Statistics

\begin{tabular}{cccccc}
\hline Variables & Mean & $\begin{array}{c}\text { Standard } \\
\text { deviation }\end{array}$ & Skewness & Kurtosis & Jarque-Bera \\
\hline GDP & 15.850 & 13.724 & 3.425 & 2.935 & $\begin{array}{c}21.427 \\
(0.000) \\
15.806^{*} \\
(0.000) \\
34.253^{*} \\
\text { LEC }\end{array}$ \\
LOP & 7.792 & 7.260 & 10.035 & 3.843 & $(0.000)$ \\
LEIN & 5.973 & 2.467 & 0.246 & 4.452 & $\begin{array}{c}45.752^{*} \\
(0.000)\end{array}$ \\
\hline
\end{tabular}

Significant at 1 and 5\% levels. Figures in ( ) denote p-values

Table 2 Correlation Statistic

\begin{tabular}{lllll}
\hline & LGDP & LEC & LOP & LEIN \\
\hline LGDP & $\mathbf{1 . 0 0 0}$ & & & \\
LEC & $--0.045^{* *}$ & $\mathbf{1 . 0 0 0}$ & & \\
& $(0.0468)$ & & & \\
LOP & $-0.037^{* *}$ & $-0.012^{*}$ & $\mathbf{1 . 0 0 0}$ & \\
& $(0.576)$ & $(0.000)$ & & $\mathbf{1 . 0 0 0}$ \\
& $0.165^{*}$ & $-0.072^{* *}$ & $0.287^{*}$ & $\mathbf{1 0 0 0 )}$ \\
LEIN & $(0.001)$ & $(0.022)$ & $(0.000)$ & \\
\hline
\end{tabular}

\subsection{Unit Root}

In the analysis, we looked at the presence of non-stationary stochastic powers. We used Augmented DickeyFuller (ADF), as well as the Phillip Perron (PP) tests of unit roots. Table 5 presents the stationary effects of all variables used, indicating the first difference stationary properties of the various unit-root solution. As such, the 
Volume: 9 | Issue: 5 |August 2021 || SJIF Impact Factor (2021): 7.254 || Journal DOI: 10.36713/epra1213

tests of ADF and PP show I(1) stationarity results at a 1\% significance level.

Table 3 Unit Root Test

\begin{tabular}{llrlc} 
& ADF & & \multicolumn{2}{c}{ PP } \\
& \multicolumn{1}{c}{ At level } & At first diff & \multicolumn{1}{c}{ At level } & At first diff \\
\hline LGDP & 0.632 & $4.246^{*}$ & 0.010 & $5.251^{*}$ \\
& $(0.240)$ & $(0.000)$ & $(2.100)$ & $(0.000)$ \\
LEC & 0.252 & $3.284^{*}$ & 0.082 & $3.023^{*}$ \\
& $(0.401)$ & $(0.000)$ & $(2.109)$ & $(0.020)$ \\
LEIN & 1.542 & $3.245^{*}$ & 0.241 & $7.172^{*}$ \\
& $(0.340)$ & $(0.000)$ & $(0.086)$ & $(0.000)$ \\
LOP & 1.207 & $2.721^{*}$ & 0.941 & $4.973^{*}$ \\
& $(4.001)$ & $(0.000)$ & $(2.042)$ & $(0.000)$
\end{tabular}

Note: $* *$ and $*$ denotes in $5 \%$ and $1 \%$ levels. The $\mathrm{p}$-values are in the brackets.

\subsection{Co-integration Result}

The F-statistics are calculated using the bound test methodology once the amount of integration among the variables has been validated. The results show that the Fstatistics is more than the appropriate critical value of the upper and lower bounds at the 1\% and 5\% levels of significance, respectively. As a result, the null hypothesis of no cointegration among the variables of interest is rejected. Specifically, as a result of these results, it is shown that long-run relationship among the OP, EIN and EC exists..

Table 4 Bound Test Result

\begin{tabular}{|l|c|c|c|c|}
\hline \multicolumn{1}{|c|}{ Level of Sig } & 1\% sig. Level & & 5\% sig. level & \\
\hline Critical Bound & Lower $(0)$ & Upper $(1)$ & Lower $(0)$ & Upper $(1)$ \\
\hline Critical Value & 3.41 & 4.23 & 3.42 & 5.32 \\
F-Statistics & 8.651 & & & \\
$k$ & 4 & & & \\
\hline
\end{tabular}

Diagnostic Tests

$\begin{array}{cccc} & \chi_{N T}^{2} & \chi_{S E R I A L}^{2} & \chi_{A R C H}^{2} \\ \mathrm{GDP}=\mathrm{F}(\mathrm{OP}, \mathrm{EIN}, \mathrm{EC}) & 0.812 & 0.713 & 0.564 \\ & (0.762) & (0.293) & (0.137)\end{array}$

All the P-values in the three diagnostic tests above are insignificance. Hence, the data is said to be free from serial correlation and heteroscedasticity; also, the normality test shows the data is normally distributed.

\subsection{Causality Result}

Table 4 shows the results of the Toda-Yamamoto (TY) causality test used to examine the relationship between energy price, energy intensity, energy usage, and economic development. This method allows us to analyze the causal nexus utilizing raw data without the need for differentiation, which is required by the traditional granger causality methodology. As a result, unlike previous research on the issue, the original qualities of the data are preserved, as is the nature of the causal link between the variables. The Toda-Yamamoto causality results in Table 4 below revealed bidirectional running from energy consumption to economic growth, energy prices to economic growth and energy intensity to economic growth. The findings supported the energyled growth hypothesis and in line with (5) and (15).

Table 5 Toda-Yamamoto Causality Results

\begin{tabular}{l|l|l|l}
\hline \multicolumn{1}{c|}{ Null hypothesis. } & \multicolumn{1}{c|}{ W-Stat. } & \multicolumn{1}{c}{ P-value } & \multicolumn{1}{c}{ Decision } \\
\hline GDP does not cause EC & 2.327 & 0.010 & Reject \\
\hline EC does not cause GDP & 4.730 & 0.000 & Reject \\
\hline GDP does not cause EIN & 3.872 & 0.000 & Reject \\
\hline EIN does not cause GDP & 51.0253 & 0.000 & Reject \\
\hline GDP does not cause OP & 7.963 & 0.028 & Reject \\
\hline OP does not cause GDP & 32.264 & 0.000 & Reject
\end{tabular}




\section{CONCLUSION AND POLICY RECOMMENDATION}

This paper evaluated the causal relationship between the energy sector and the real sector by taking in to account energy use, energy intensity and energy price as factors influencing economic growth in the case of Nigerian economy from 1980 to 2020. All preliminary tests were conducted in order to validate the data and have a clear picture of what it looks like. The bound test co-integration relationship approach is used to determine the variability of energy use, energy intensity, energy price and economic growth.

The Toda-Yamamoto causality test is used to investigate the direction of causation. Our findings imply that increasing energy use, energy intensity, and energy prices boosts economic growth. This demonstrates a bidirectional causal effect. As a result, the neoclassical premise that energy is neutral for growth is rejected. This pattern is similar to the findings of (19), (7), (17), and (2). As a result, we conclude that energy is a decisive component of GDP growth in the Nigerian economy, and that strong economic growth leads to high energy consumption, and vice versa. As a result, while developing energy conservation regulations, it is critical to consider the potential negative consequences on economic growth.

Policies to combat environmental pollutants necessitate the determination of particular priorities in order to lower initial costs and increase investment efficiency. Reducing energy consumption, boosting energy supply investment, and improving energy efficiency may all be implemented without harming Nigeria's economic growth and, as a result, lowering emissions. Simultaneously, efforts must be made to encourage industry to embrace innovative technology that reduce pollution. Finally, given the significant energy subsidies in the exporting nations, there is substantially more headroom for more radical energy conservation measures with little impact on economic development in these nations. Indeed, it is doubtful that eliminating energy pricing distortions will stifle economic growth in oil-producing countries. Subsidy reform, on the other hand, should be included in a reform program that garners public support and provides widespread benefits.

\section{REFERENCE}

1. Ali, M., \& Aittokallio, T. (2019). Machine learning and feature selection for drug response prediction in precision oncology applications. Biophysical Reviews, 11(1), 31-39.

2. Apergis, N., \& Payne, J. E. (2009). CO2 emissions, energy usage, and output in Central America. Energy Policy, 37(8), 3282-3286

3. Apergis, N., \& Payne, J. E. (2010). Renewable energy consumption and growth in Eurasia. Energy Economics, 32(6), 1392-1397

4. Apergis, N., Payne, J. E., Menyah, K., \& Wolde-Rufael, Y. (2010). On the causal dynamics between emissions, nuclear energy, renewable energy, and economic growth. Ecological Economics, 69(11), 2255-2260

5. Bayer, C., \& Hanck, C. (2013). Combining non- co-integration tests. Journal of Time Series Analysis , 34(1), 83 -95 .

6. Bekun, F. V., Emir, F., \& Sarkodie, S. A. (2019). Another look at the relationship between energy consumption, carbon dioxide emissions, and economic growth in South Africa. Science of the Total Environment , 655, 759 -765

7. Brown, M. B. (2019). Africa's choices: after thirty years of the World Bank. Routledge. Burbidge, J., \& Harrison, A. (1984). Testing for the effects of oil - price rises using vector autoregressions. International Economic Review, $459-484$.

8. Darby, M. R. (1982). The price of oil and world inflation and recession. The American Economic Review , 72(4), $738-751$.

9. Gisser, M., \& Goodwin, T. H. (1986). Crude oil and the macroeconomy: Tests of some popular notions: Note. Journal of Money, Credit and Banking, 18(1), 95 -103.

10. Granger, C. W. (1969). Investigating causal relations by econometric models and cross -spectral methods. Econometrical: Journal of the Econometric Society, 424 -438

11. Heller, B., Seetharaman, S., Mahadevan, P., Yiakoumis, Y., Sharma, P., Banerjee, S., \& McKeown, N. (2010, April). Elastic -tree: Saving energy in data centre networks. In Nadi (Vol. 10, pp. 249 -264)

12. Johansen, S. (1988). Statistical analysis of co -integration vectors. Journal of economic dynamics and control, $12(2-3), 231-254$.

13. Larsson, T. B. (2001). Biodiversity evaluation tools for European forests. Criteria and Indicators for Sustainable Forest Management at the Forest Management Unit Level, 75.

14. Mankiw, N. G., Romer, D., \& Weil, D. N. (1992). A contribution to the empirics of economic growth. The quarterly journal of economics , 107(2), $407-437$

15. Mork, K. A. (1989). Oil and the macroeconomy when prices go up and down: an extension of Hamilton's results. Journal of Political Economy, 97(3), 740 -744.

16. Nasreen, S., \& Anwar, S. (2014). A causal relationship between trade openness, economic growth, and energy consumption: A panel data analysis of Asian countries. Energy Policy, 69, 82 -91 
ISSN: 2347-7431

EPRA International Journal of Climate and Resource Economic Review

-Peer Reviewed Journal

Volume: 9 | Issue: 5 |August 2021 || SJIF Impact Factor (2021): 7.254 || Journal DOI: 10.36713/epra1213

17. Parsa, H., \& Sajjadi, S. Z. (2017). Exploring the trade openness, energy consumption, and economic growth relationship in Iran by Bayer and Hanck combined co -integration and causality analysis. Iranian Economic Review, 21(4), $829-845$.

18. Pedroni, P. (1999). Critical values for co -integration tests in heterogeneous panels with multiple regressors. Oxford Bulletin of Economics and Statistics , 61(S1), 653 -670.

19. Pesaran, M. H., Shin, Y., \& Smith, R. J. (2001). Bounds testing approaches to the analysis of level relationships. Journal of applied econometrics , 16(3), 289 -326

20. Poveda, A. C., \& Martinez, C. I. P. (2011). Trends in economic growth, poverty, and energy in Colombia: long run and short -run effects. Energy Systems , 2(3 -4), 281 -298

21. Rasche, R. H., \& Tatom, J. A. (1977). Energy resources and potential GNP. Federal Reserve Bank of St. Louis Review, (Jun), $10-24$.

22. Samu, R., Bekun, F. V., \& Fahrioglu, M. (2019). Electricity consumption and economic growth nexus in Zimbabwe revisited: fresh evidence from Maki co -integration. International Journal of Green Energy, 16(7), 540 $-550$

23. Schajowicz, F., Ubios, A. M., Araujo, E. S., \& Cabrini, R. L. (1985). Virus -like intranuclear inclusions in giant cell tumour of bone. Clinical Orthopedics and related research, (201), 247 -250

24. Shahbaz, M., Zeshan, M., \& Afza, T. (2012). Is energy consumption adequate to spur economic growth in Pakistan? New evidence from bounds test to level relationships and Granger causality tests. Economic Modelling , 29(6), $2310-2319$

25. Zhou, P., \& Ang, B. W. (2008). Linear programming models for measuring economy -wide energy efficiency performance. Energy Policy, 36(8), 2911 -2916. 